\title{
Harmonization of the Education Curriculum at Pesantren Al Falah Gorontalo: An Educational Philosophy Study
}

Shely Cathrin ${ }^{1}$, Reno Wikandaru ${ }^{2}$, Indah Listiana ${ }^{3}$, Devi Ratnasari ${ }^{4}$, Warsidah Warsidah ${ }^{5}$, Widyoningsih Widyoningsih ${ }^{6}$, M. Bahtiar Arif", and Astrid Veranita Indah ${ }^{8}$

${ }^{1}$ Educational Policy Study Program, Universitas Negeri Yogyakarta

${ }^{2}$ Universitas Gadjah Mada

${ }^{3}$ Universitas Lampung

${ }^{4}$ Universitas Indraprasta PGRI Jakarta

${ }^{5}$ Universitas Tanjungpura

${ }^{6}$ STIKES Al Irsyad Al Islamiyyah Cilacap

${ }^{7}$ Universitas Islam Raden Rahmat Malang

${ }^{8}$ Universitas Islam Negeri Alauddin Makassar

ORCID:

Shely Cathrin: https://orcid.org/0000-0003-4883-7187

Corresponding Author:

Reno Wikandaru

renowikandaru@ugm.ac.id

Published: 29 December 2021

Publishing services provided by

Knowledge E

(c) Shely Cathrin et al. This

article is distributed under the

terms of the Creative Commons

Attribution License, which

permits unrestricted use and

redistribution provided that the

original author and source are

credited.

Selection and Peer-review under the responsibility of the ICMEd Conference Committee.

\section{Abstract}

Pesantren (Islamic boarding schools) have become character-building institutions trusted by the Indonesian people; however, as educational institutions, pesantren must adapt to the national education curriculum which can be challenging. The purpose of this study was to critically identify and analyze the implementation of the educational curriculum at the pesantren Al Falah Gorontalo, based on the educational philosophy point of view. A qualitative approach was employed, using the hermeneutics method. Interpretation, description, synthetic analysis, internal coherence, holistic, reflection, and heuristics were used. The results indicated that the pesantren Al Falah Gorontalo combined two educational curriculums. Analysis from the educational philosophy perspective found that the implementation of education was based on essentialism educational philosophical ideas, which assume that education is full of flexibility and helps students to adhere to noble values, spiritual characteristics, and human guidance to achieve a more noble life.

Keywords: pesantren, curriculum, combination, essentialism, education

\section{Introduction}

Educational model in pesantren (islamic boarding school) always deals with a classic problem. Pesantren education is a trusted educational institution by community in a long period for character building and attitude development. However, on the other hand, pesantren is obliged to adapt with the national education system. As a country which has major moslem community, character building education in pesantren is one of 
Indonesia needs to improve the national educational curriculum by means of containing different group types based on religions, tribes, etc. Hereby, a pesantren dilemma happens as likely never ends. Until now, pesantren is finally urged to choose based on pesantren and national curriculum. Not all pesantren can perform this choice well [1].

Pesantren has become a place with important part in Indonesian national history. Education tradition in pesantren is closed to Indonesian community tradition, far before Indonesia Independence. From those pesantren, national people were also born with not only wise and religious, but also nationalist. When heard about pesantren, everyone who has been in contact with its reality, will be brought to a dynamic, religious, scientific, and exotic life nuance. It is possible that pesantren will lead to an insight of a place to learn orthodox, static, exclusive, and traditional religion. Pondok pesantren as the oldest institution in Indonesia always conserves the traditional learning educational values [2]. This system and technological conservation that make pesantren with this model called as pesantren. These values conservation can be easily tracked in a pesantren student that lives in a simplicity, unrewarded learning, and full of responsibility, as well as bound to high solidarity[3]

Pesantren as an Islamic religion based educational institution in Indonesia has been contributed to build a student with balanced intellectual and spiritual composition. Pesantren education plays an important role in attitude education [4]. Some important people in the Indonesian national movement were also born from this pesantren education learning. Independent, responsible, along with spirituality and religious obedient become the important factors to build a pesantren student characteristics. Pesantren still takes the important position until now in social life, as well as nationality and country politicism.

As the time passes, a period keeps changing. Challenges faced by pesantren nowadays are also more complex and urgent due to the improvement of developmental requirement and IPTEK (science and technology). In this condition, pesantren is expected to be capable of determining the ideal behavior that gives a solution for the challenge, as well as still protecting the pesantren function as an educational and da'wah institution [5]. One effort that should be done is by continuously adjusting the pesantren educational curriculum required for period development, including national educational curriculum. Pesantren curriculum adjustment with national curriculum sometimes does not perform smoothly.

A harmonization problem of pesantren curriculum integration becomes a classic problem of pesantren. Meanwhile, there are less studies discussing about the educational program in pesantren. One cause is due to most people presume that pesantren 
education has a different learning method with formal education in Indonesia. Discussion about pedagogical aspects of pesantren education based on history, curriculum, learning method, and educational philosophical course are still rarely found [6].

Researchers analyze that the pesantren education problems above can be answered and analyzed through philosophical viewpoint, especially educational philosophical discussion. Reasons of selected educational philosophical discussion is due to philosophy is an analysis that can answer a problem comprehensively regarding to educational sector. Educational philosophy can be become a deep knife analysis to discover the educational aspects performed in the pesantren. Researchers took the study object in Pesantren Al-Falah Gorontalo with some considerations. First, a necessity to discuss pesantren in non-Java Island region. Second, Pesantren Al Falah Linggoto Gorontalo is one of pesantren known to have good reputation and educational quality. Radical-philosophical study is performed to identify the philosophical aspects that answer the basic problem related to the pesantren educational contribution for high school pesantren student character building in Indonesia. This study is an explorativephilosophical study, therefore aimed to dig and discover a picture about pesantren educational philosophy practical especially in Pesantren Al Falah Tunggulo Limboto Gorontalo as well as its contribution for pesantren student character building education in Indonesia.

An empirical deep discussion about the pesantren educational practice in Indonesia, as well as abstracting it can discover a pesantren educational concept that can give a contribution for highschool pesantren student character building in Indonesia. This article will attempt to answer two questions, how curriculum is implemented in the education system of Pesantren Al Falah Tunggulo Lomboto Gorontalo; and how the course of educational philosophy used as an educational foundation of Pesantren Al Falah Tunggulo Limboto Gorontalo.

\section{Related Works}

The issue of the pesantren curriculum has always been an interesting topic to be studied in the field of education. On the one hand, pesantren has an educational model that is proven to be effective in shaping the character and behavior of students. On the other hand, there are regulations or government regarding standardization of the national curriculum. This regulation leaves pesantren with no other choice but to adapt to nationally applicable educational standards. This is not always easy to do. With 
the limited time for teaching and learning, pesantren sometimes also find it difficult to synergize the existing curriculum. The quality of the education carried out is at stake.

The issue of curriculum management that applies in this pesantren has attracted the attention of several researchers in the field of education. Based on a search for references with the keyword "Islamic boarding school curriculum" on the Garuda portal, the author found as many as 170 scientific articles containing this keyword. Of these, there are several studies that are relevant to the topics discussed in this article. The first is Abdurrahman's research conducted in 2018, and published in At Turas, the Journal of Islamic Studies. Abdurrahman's research is an important reference in writing this article because it provides information about the implementation of policies implemented by pesantren, in combining the new curriculum and the pesantren curriculum [1]. One of the important findings of this research is the policy taken by pesantren to implement two curricula at once, namely the pesantren curriculum itself and the national education curriculum.

Second, is the research conducted by Kusnandi entitled Integration of Islamic Boarding School-Based Curriculum in Educational Institutions. This article was published in the Journal of Education in 2017. This article is an important reference for writing this article because it provides knowledge about the integration of the pesantren curriculum carried out by public schools [2]. Kusnandi's research indirectly also strengthens the argument about the superiority of the pesantren curriculum in shaping the character and character of students in accordance with the competency standards set by the school.

The third is a study entitled "The Dynamics of Changes in the Curriculum of Madrasah Diniyah Pondok Pesantren Putri Lirboyo al-Mahrusiyah Kediri" conducted by Rhoyachin and Wahyuni in 2019. This research reveals the dynamics that occur in one of the Islamic boarding schools in responding to the challenges of curriculum changes in line with developments that occur in the world of education. Similar to the two studies previously described, this study also shows the efforts made by Islamic boarding schools in Indonesia in responding to developments in the world of education.

Some of the studies described above show one thing that is important in the world of Islamic boarding school education in Indonesia, namely the efforts made by pesantren to integrate the existing educational curriculum. However, these studies have not shown in detail the efforts or strategies undertaken by pesantren to harmonize the existing curriculum. This gap will be discussed in this research. By examining the implementation of the teaching and learning process at the AI Falah Islamic Boarding School, Gorontalo, 
this study aims to describe the process of harmonization of the educational curriculum applied in this pesantren.

\section{Methodology}

This study was a library-research study which is emphasized with a deep interview. Target of this study was the teachers at Pesantren Al Falah Tunggulo Limboto Gorontalo. Data in this study were obtained from reference discussion either on books, journal, magazines, newspapers, articles, or writings from other sources that discuss about pesantren education. Data were also obtained through observation, interview with students and teachers in Pesantren Al-Falah Gorontalo, and questionnaire distributed to pesantren students. This effort is a method to ensure data validity obtained from references as well as gaining a new information undiscovered from reference discussion regarding to the studied object. The study subject was the head of Pesantren, head of MA and MTs, MA and MTs teachers, and tutors, as well as pesantren students of Pesantren Al Falah Tunggulo Limboto Gorontalo. Furthermore, the study object contained 2 objects, namely material and formal object. Material object discussed in this study was the education of Pesantren Al Falah Tunggulo Limboto Gorontalo while the formal object was educational philosophical perspective. The study setting was Pesantren Al Falah Tunggulo Limboto Gorontalo as an institution for learning and repurifying Islam, therefore in Muhammadiyah people specifically and Islam people generally can apply an Islamic theory that follows Rasullullah (Muhammad) guidance from al-Qur'an and as-Sunnah. Pesantren Al Falah is located at JL. Ki Hadjar Dewantoro, Tunggulo, Limboto, Gorontalo 96271. The study was performed in 3 months, from February until June, 2020.

This study was aimed to investigate the basic and general insight that underlined the pesantren educational system, especially on Pesantren Al-Falah, therefore can be identified this pesantren contribution for pesantren student character building. An investigation about the main foundation that established the education of Pesantren Al-Falah was performed against some aspects, namely education goals, pedagogy aspects, learning method as well as educational course, and educational philosophy. Methodical elements used in this study contained description methodical unsure, analytico-synthesis, abstraction, interpretation, reflection, coherence-inherent, holistic, and heuristic. Data validity in this study used source triangulation and technique. Source triangulation by performing data cross-check from three data sources, namely head of Pesantren, head of MA and MTs, MA and MTs teachers, and tutors, as well as pesantren 
students of Pesantren Al Falah Tunggulo Limboto Gorontalo. Triangulation technique is a cross-check on preference discussion, observation, and interview.

\section{Results and Discussion}

\subsection{About Pesantren Al Falah Linggoto Gorontalo}

Pesantren Al Falah Gorontalo is one of pesantren in Indonesia. The pesantren is located in Jl. Ki Hadjar Dewantoro, Tunggulo Village, Limboto Barat District, Gorontalo Regency, Gorontalo Province. This pesantren was established by KH. Hamrain Kau. Pesantren student in Pesantren Al-Falah has background and reasons to study there. There are ones who comes from their own willingness and also who are insisted by their parents. Total student in Pesantren Al-Falah is about 500 students with each male and female student boarding house are on the same place. The challenges are hard followed by strict control in a different environment. Total female student is less than male student.

Pesantren Al-Falah Linggoto was established with some goals. First, to build a student with akhlaqul karimah. Second, to build students who can unite ummah, not separating it, therefore the motto of Pesantren Al-Falah is above and for all groups. Third, student can be useful for country and nation. Pesantren Al-Falah has a noble goal, as well as showing that Pesantren Al-Falah tries to create a student with good religion understanding that can be used for uniting the nation. In other words, Pesantren Al-Falah tries to show that religious knowledge can be used for kindness and benefit for all Indonesian nation.

Based on the researcher observation, one of special terms in Pesantren Al-Falah is its characteristics or goal for "uniting nation" as pesantren commonly has other goals apart from akhlaqul karimah. Moreover, this condition presents that student in this pesantren are accepted from any tribes without choosing. One effort to show the integrative function can be identified from the Pesantren Al-Falah effort in teaching some mazhab figh for students. The goal is to make students understand that there some perspectives or insights, therefore not easily blaming other mazhab; such as taking wudlu, etc.

Fiqh problem is an important aspect in pesantren education. As related to the fiqh problem, pesantren teaches 4 mahzab in minimum, namely mahzab Hambali, Safi'l, Hanafi, and Maliki. Parents at the beginning have an insight that Pesantren Al-Falah has a certain mazhab, yet after understanding that Pesantren Al-Falah also teaches some mazhab; parents can accept and understand that there are some different mahzab or courses, but not becoming a conflict. Students are taught about various mahzab with 
the goal of shaping students live and adapt with any groups with any mahzab, therefore students can accept a contradictive insight from other groups.

Pesantren Al-Falah in figh term takes from some sources, such as Bidatul Mustahid, thus becoming an effort to build a tolerance behavior. Tolerance behavior is expected to build the student character who can understand other insights, not only different insight in nationality and country, but also religious insights or mahzab. This character can anticipate the intolerant behavior against other insights. In this sub section, the results of this work are presented.

\subsection{Educational Curriculum in Pesantren Al Falah Gorontalo}

As one of educational institutions, Pesantren Al-Falah has some madrasah (school), either ibtidaiyah, tsanawiyah, or aliyah level. Curriculum used on the educational activity in madrasah is a curriculum originated from Indonesian Ministry of Religious Affairs and pesantren. A curriculum combination between Indonesian Ministry of Religious Affairs and pesantren is applied on madrasah tsanawiyah and aliyah educational level. Pesantren curriculum is re-used after learning in MA and MTS. Based on the information obtained from the interview results with Ms. Maziah, the madrasah curriculum used in Pesantren Al-Falah is similar to the curriculum used in all madrasah of Indonesia following the ministry of religious affairs regulation, namely; $30 \%$ religion education and $70 \%$ general knowledge. Meanwhile for pesantren curriculum, $100 \%$ is religion education for Pesantren Al-Falah (interview with Maziah; head of Madrasah).

Curriculum applied in Pondok Pesantren Al-Falah is halfly inspired by curriculum applied in Pondok Pesantren Gontor. This curriculum has been applied in Pondok Pesantren Al-Falah since established in 1989. The reason of applying 2 curriculums is due to madrasah curriculum is required for students to continue their educational levels, while pesantren curriculum is required for students as supplies to implement and be useful in the community (interview with Muhammad Juaini). It can be concluded that the implementation of 2 curriculums are efforts of Pesantren Al-Falah to build the student characters not only from academic-cognitive aspect, but also from social and individual characteristic aspect.

One of madrasah that became the discussion object in this study was Madrasah Aliyah (MA) Limboto Barat Gorontalo. MA Limboto Barat Gorontalo is a boarding-school based school with a vision to prepare students who are religious, knowledgeable, and generous. MA Limboto Barat Gorontalo is one of private MA in Gorontalo that combines the Indonesian Ministry of Religious Affairs and pesantren curriculum. The learning 
method used in this educational institution also combines some learning methods, such as discussion and material explanation method. This combination is conducted at the madrasah educational level. In pesantren, this madrasah uses a discussion method, then continued with question and answer, and closed with a strengthening from Ustad/Ustadzah. All students have a chance to ask and present their opinions openly.

The implementation of 2 curriculums so far in Pesantren Al-Falah has been going well and never finding a problem as conducted in a different period. The ministry of religious affairs curriculum is applied when learning in madrasah, then continued to pesantren curriculum after students come home from school and return to pondok pesantren. Madrasah curriculum begins to be applied at 07.00 a.m when the school time occurs. The implementation of these 2 curriculums does not complicate students, but strengthening their capability and knowledge at different time and way (interview with Ms. Maziah).

Based on the interview performed with Muhammad Juanini, learning media used in the learning process at madrasah is holy book, power point, and also various media such as film or story, as students are then asked to summarize the film/story and ask a question when there are some uncleared materials. Pesantren principally tries to use various media, although pesantren still many limitations for that. This limitation contains facilities and infrastructure in Pesantren Al-Falah. However, this limitation can be accepted by all teachers as challenge to look and find for alternative ways, therefore the learning process can keep going maximally.

Pesantren curriculum evaluation is performed in many ways, containing writing assessment, religious practice, praying practice, memorizing assessment, calligraphical result assessment, language conversation assessment (conversation practice). Evaluation related to entrepreneurship is unevaluated due to characterized as supplementary and additional material for students to have other capabilities. As an example, some other time, pesantren taught a wooding skill, yet due to wood was expensive and funding limitation exposed in pesantren, then Pesantren Al-Falah adjusted with another skill, namely chicken farming. Pesantren also previously taught cow farming skill. Chicken farming performed lately will commonly be sold its production as the farmer chicken is joper chicken, while the egg is hatched individually. Pesantren Al-Falah has a restaurant partner that will buy the chicken. Besides farming, pesantren has ever taught students to make flowerpot, sewing, although discontinued for a long time due to student learning period problem. 


\subsection{Educational Philosophy}

Education as one of important sectors in human life has become an important discussed object in the philosophical science. Since ancient Greek period, a discussion about education was existed and became a topic for most philosophers, such as Plato and Aristotle. Until contemporary period as nowadays, the discussion about educational philosophy still develops along with the problem complexity occurred in human life. Fast period development with many kinds of challenge given to human life makes human keep developing and performing various renewal in the education world. This renewal is conducted without no directions, but based on the philosophical consideration through educational philosophical discussion [8].

Educational philosophy according to Randal Curren is an implementation of serial philosophical beliefs in educational practice [9]. Education according to Ki Hadjar Dewantara is life guidance of children growth, namely guiding all superior powers existed on children to be a human and community member that can reach salvation and happiness as high as possible [10]. Education helps human understand the world with the dynamics in its reality, as well as helping human optimize himself in facing various nature and social challenges. Education in other words is a human effort to keep humanizing himself.

In conclusion, educational philosophy is a critical, radical, methodical, comprehensive, and systematic discussion about educational nature. This educational nature is reached through answering some fundamental, main, and basic questions, such as ontological, epistemological, and axiological dimensional questions. The ontological question in the educational world is a question about basic reality assumption in education, such as questions about world, human, and God. One of basic ontological questions in the educational philosophy sector is questions of what is the human nature? Is human physical, spiritual, or both creatures? Does human have mind, sense, intuition, or all of it? Meanwhile epistemological questions in educational philosophy adheres to the problems about what kind of true nature should be taught to students? What are the epistemological instruments should be developed by students in education process? etc. Lastly, the axiological aspect in educational philosophy discusses about what values that become the basic and goal of performing all processes in education?

Various basic problems in educational philosophy finally create some theories in educational philosophy sector. Generally, these theories are differed into four popular courses, namely progressivism, essentialism, perennialism, and existentialism [8]. The influence of progressivism course in education system extremely impacts on the whole 
world, mainly in the United States. Renewals in education sector nowadays is believed due to an urge from the progressivism course [11]. Theodore Brameld (The Pattern of Education Philosophy, 1956) in the book of "Filsafat Pendidikan Islam" connects the progressivism course with a liberal life insight, namely the liberal road to culture cited from a flexible life insight (non-hard, undeniable change, unadherred to certain doctrine), curious (willing to identify and investigate), tolerant, and open-minded[12].

Prof. H. Muzayyin Arifin, M.Ed in his book of "Filsafat Pendidikan Islam" stated that essentialism course fundamentalizes his mind from humanism course occurred against the life reaction pointing at worldly characteristics with more scientific and materialistic. Essentialism course also added with an insight from idealism course that considers the knowledge has existed in human mind or teaching subject, as well as realism that considers material world outside of human awareness is something real therefore importantly introduced and using an intelligence [13].

Essentialism philosophy is formulated as critics against progressive trends at schools, caused by progressivism philosophy bias. In this condition, Bagley and colleagues who have similar thoughts about education, are very critical against progressive education practice. They thought that progressive movement has damaged intellectual and moral standard. Schools that become a progressive thought step have failed in fulfilling a duty to transmit social and intellectual inheritance [14]. The goal is to inherit the cultural and historical inheritance through main accumulated basic knowledge and sustained in a long period, as well as an assessed life in a long term period, moreover essentialism educational goal is to prepare human to live, which means school contributes on how design a goal with various materials, which finally available for preparing a human life [15]. Various kinds of insight in educational philosophy is continuously used as a view point to analyze dimension or philosophical aspect during education activity in pesantren Al Falah Gorontalo. One of main goals in this study is the implementation of double curriculums in pesantren Al Falah Gorontalo.

\subsection{Educational Philosophical Explanation against Educational Curriculum in Pesantren Al Falah Gorontalo}

Educational philosophy, as philosophical part that reflects critically on the education activity has important position or role. One reason is due to educational philosophy facilitates the evaluation of various aspects in education activity, whether the education performed follows the initial goal of education or not. One analysis object for educational 
philosophy is educational curriculum, whether curriculum applied follows the education goal or not.

Human world with its dynamics always presents new challenge in human life. There is no other ways for each educational institution, including pesantren in Indonesia to respond the dynamics, except by continuously fixing, changing, and adjusting. Nurcholis Madjid emphasized that pesantren is Indonesian civilization artefact constructed as traditionally, unique, and indigenously religious educational institution[16]. Although pesantren have become a dependable character-building institution for a long time, pesantren should adapt to various change happened in the education world. One adaptation is in the form of curriculum adaptation as conducted by pesantren Al Falah Gorontalo.

The curriculum combination in Pesantren Al Falah Gorontalo is an effort performed by pesantren to contextualize the education activity with periodical development and demand. Education is not only about knowledge transfer process, but also process for preparing the human to survive in his life. Education therefore is a process with a noble goal. Not only enough for supplying students with cognitive knowledge, but also supplying students' various skills or other capabilities. Gerald Lee Gutek even mentioned that education is a social process that teaches human about the way to live in a culture [13]. Education is a process of humanizing human. Education is human learning process to be ideal as imagined or aspired. The curriculum combination performed by Pesantren Al Falah Gorontalo as explained above is one model for pesantren in adapting on various kinds of periodical change and demand. Whether curriculum combination can perform effectively or not, can be evaluated from educational philosophical insight, as well as the curriculum effectiveness performed in pesantren to reach or realize the education goals.

To reach until an understanding about educational nature, educational philosophy reflection is at least started from three problems. First, educational philosophy reflects on the educational nature. The main question is about "what actually is education?" The answer for this question will be varied. Each course or insight of educational philosophy will commonly have different insights. Second, educational philosophy reflects on the education goals. One educational course may tell that the main goal of education is to perform a knowledge transfer. Meanwhile other educational philosopher stated that the education goal is to polish skills or to train the student creativity. Third, the value problem in education can also become reflection tool as an effort to reach educational nature. Certain insight or course in educational philosophy may think that the most important value in education process is spiritual value. Other courses may think creativity, etc. 
These three problems are also used to analyze the educational curriculum in Pesantren Al Falah Gorontalo from educational philosophy viewpoint.

The main problem that becomes the analysis of educational philosophy against education activity in Pesantren Al Falah Gorontalo is educational nature problem. This problem is related to an understanding of general education meaning, related to the question about the actual meaning of education. Each educational institution or agency, either formal or non-formal can exactly have a certain understanding about this education. The same understanding is even owned by human generally. Education can be understood simply as knowledge transfer process, or far more than that. Pesantren Al Falah Gorontalo as religion based educational institution also has an understanding about education nature.

Pesantren has long been known as a character-building institution. Therefore, character and and behavior education become one of the characteristics differing pesantren with other institutions. Pesantren Al Falah Gorontalo also has a similar understanding. For pesantren and religion based educational institutions, the educational process is naturally understood as a process to prepare sholeh-sholehah human, faithful human, as well as doing and sustaining the religion values in daily behavior and habit. Therefore, education in pesantren teaches various kinds of holy books and fiqh that become a fundamental in human connection with God. This condition can be seen on the education activity in Pesantren Al Falah Gorontalo. During the interview, Pesantren Al Falah Gorontalo committee said that this pesantren also taught mahzab known in fiqh problems. One characteristic that makes Pesantren Al Falah Gorontalo special is on the educational process that teaches students to be open-minded. This occurs in an effort performed by pesantren by teaching not only one mahzab to students. This effort may not be performed by other pesantren due to sometimes only teaching to believe in one mahzab and teaches the students to only believe in it.

Openness that can be seen in education pattern of Pesantren Al Falah Gorontalo shows that for this pesantren, education is not always related to praying. Education is not only preparing students to be faithful humans and doing the religion obligation. Moreover, Pesantren Al Falah Gorontalo teaches the way to openly think as true diversity is fitrah [17]. Instead of imposing one mahzab to the students, this pesantren is more preferred to select which mahzab they believe in. The freedom given by the pesantren committee to students indicates that the educational process in Pesantren Al Falah Gorontalo is not only understood as a process to build sholeh moslem generation and religiously obedient, but also making the education as a process to increase the human degree on a more noble position. Education is a process to humanize human. 
As a process of humanizing human, religion knowledge supply is insufficient for students. Students need to be supplied with various knowledge and skills about other things, such as knowledge and skill in general and enterpreneural science. Basic knowledge and skills are prepared by Pesantren Al Falah Gorontalo in the form of formal school establishment, such as madrasah ibtidaiyah, madrasah tsanawiyah, and madrasah aliyah. These madrasahs were actually established as pesantren effort to prepare students more ready in facing the periodical demands. By joining the formal education, students will achieve diploma, as a formal legal document used by students for job vacancy or continuing onto a higher education level. Formal education in this pesantren becomes one of the proofs that pesantren prepares the students to follow the requirement and qualification applied in the community.

Educational philosophy discussion acknowledges many kinds of courses and insights, such as essentialism, progressivism, perennialism, etc. [13]. After concerning on various viewpoints about the educational nature, it can be concluded that the educational activity in Pesantren Al Falah Gorontalo shows principals as discovered in the essentialism educational philosophical course. The essentialism educational philosophical course is an educational course that pinpoints at the educational process against the effort to supply the students with various skills and essential knowledge for life. As an example, the skill of reading, writing, art, and many kinds of essential skills. These skills and knowledge supply is important to be given to the students due to skills are considered essential for leading the human into a good life and well-being, as expected by human generally [13].

Some essential educational course aspects can be discovered on the knowledge supply given by Pesantren Al Falah Gorontalo to all students. This supply contains knowledge about formal education in madrasah, entrepreneurial skill supply in the form of animal farming training, as well as religion knowledge taught in pesantren. Various knowledge and skills are given as supplies for students to fulfill wellbeing or better and noble life as expected. There are variations discovered from various kinds of knowledge and skills affected by the basic insight from pesantren committee against the educational process. For Pesantren AI Falah Gorontalo, religion knowledge supply is one of important supplies for students in doing their lives. Therefore, religion knowledge is also considered as an essential stuff, thus taught to all students.

Entrepreneurial knowledge and cognitive capability taught to all students through madrasah is efforts to supply the students with knowledge to live in the world by means of facing some challenges in life. This insight indirectly points at the conclusion about the educational nature, which for Pesantren Al Falah Gorontalo, well-being or better 
life will be achieved by human to not only worldly live better, but also well-being in aspects related to after life. Both should be balanced as taught in Islamic religion as fundamental values in educational activity in pesantren.

The second problem used as an analysis to reach understanding about the educational nature is about the education goals. Aspects of questions about these goals are related to the first aspect, or educational nature aspect as explained above. For pesantren educational institution, the educational goal generally performed is to prepare the generations or students to be faithful and believe in Allah SWT. Pesantren in other words is an education that proposes to build a religious generation, religiously obedient, as well as upholding the morality values. This pesantren educational goal is commonly found on the educational process in Pesantren Al Falah Gorontalo. Strong religion-based learning in this pesantren can be identified from the religious values shown in the learning process, either from students or pesantren committee.

\section{Conclusion}

Challenges and dynamics faced by pesantren should actually be responded well by each educational institution in Indonesia, specifically by Pesantren Al Falah Gorontalo. Based on the analysis results, it can be concluded that Pesantren Al Falah Gorontalo combines two curriculums together, namely Indonesian Ministry of Religion Affairs curriculum and pesantren curriculum. Therefore, this pesantren perform both curriculums with an integrated pattern. Ministry of Religion Affairs curriculum is performed in madrasah, while pesantren curriculum is performed after coming from madrasah.

Based on the study discovery, it can be concluded that the educational practice performed in Pesantren Al Falah Gorontalo shows an essentialism educational course, namely an educational philosophical course that aims to provide essential skills for students, such as essential or basic knowledge and skills for daily lives. This can be identified from the learning process as well as educational goals regulated by the pesantren committee.

\section{Acknowledgement}

This research is fully supported by Universitas Negeri Yogyakarta. 


\section{References}

[1] Faizin I. Lembaga pendidikan pesantren dan tantangan global. Madaniyah. 2020;10(1):89-116.

[2] Syafe'i I. Pondok pesantren: Lembaga pendidikan pembentukan karakter. AlTadzkiyyah Jurnal Pendidikan Islam. 2017;8(1):61-82. doi: 10.24042/atjpi.v8i1.2097

[3] Geertz C. Abangan, santri, priyayi dalam masyarakat Jawa. Jakarta: Dunia Pustaka Jaya; 1981.

[4] Murdiono M, Miftahuddin M, Kuncorowati PW. The education of the national character of pancasila in secondary school based on pesantren. Jurnal Cakrawala Pendidikan. 2017;36(3):423-434.

[5] Toni D. Pesantren sebagai potensi pengembangan dakwah Islam. Jurnal Dakwah dan Komunikasi. 2016;1(1):97-110.

[6] Atmojo AEP. Pesantren dalam budaya Pendidikan. IBDA‘ Jurnal Kajian Islam dan Budaya. 2014;12(2):172-184.

[7] Bakker A, Zubair AC. Metodologi penelitian filsafat. Yogyakarta: Kanisius; 1994.

[8] Barnadib I. Filsafat pendidikan. Yogyakarta: AdiCita; 2002.

[9] Curren RR. Philosophy of education: An anthology. Wiley-Blackwell; 2006.

[10] Suparlan H. Filsafat pendidikan Ki Hadjar Dewantara dan sumbangannya bagi pendidikan Indonesia. Jurnal Filsafat “WISDOM”. 2014;24(1):1-19.

[11] Wikandaru R. Aliran pendidikan progresivisme dan kontribusinya dalam pengembangan pendidikan pancasila di Indonesia. Jurnal IImiah CIVIS. 2012;2(1):143-155.

[12] Arifin HM. Filsafat pendidikan Islam. Jakarta: Bumi Aksara; 2000.

[13] Gutek GL. Philosophical alternatives in education. Ohio: Merrill Publishing Company; 1974.

[14] Sadulloh U. Pengantar filsafat pendidikan. Bandung: Alfabeta; 2004.

[15] Ghufron A, Budiningsih, CA, Hidayati, H. Pengembangan pembelajaran berbasis nilai-nilai budaya yogyakarta di sekolah dasar. Jurnal Cakrawala Pendidikan. 2017;36(2):309-319. doi:10.21831/cp.v36i2.12449

[16] Haedari A. Masa depan pesantren. Jakarta: IRD Press; 2004.

[17] Wibisono MY. Pluralisme agama dan perubahan sosial dalam perspektif Islam. Religious Jurnal Studi Agama-Agama dan Lintas Budaya. 2016;1(1):11-24. 